\title{
The Overseas Demand For Tourism In The United States"
}

\author{
William STRONGE*
}

Ever since World War II, there has been an annual exodus of U.S. tourists to overseas countries. Between 1960 and 1981, the number of U.S. residents who traveled overseas increased from 1.634 million to 8.040 million, an increase of almost 400 percent. Phenomenal as this growth was, however, it was overshadowed by the growth in the number of overseas residents who visited the United States. Between 1960 and 1981, the number of overseas visitors to the United States increased from 0.602 million to 8.069 million, an increase of over 1200 percent.

This paper presents an analysis of U.S. exports of tourism to overseas residents. Section one presents a descriptive analysis of the importance of tourism for the U.S. balance of international payments. This is followed by an analysis of overseas tourist exports in the second section. An econometric estimation of price income and airfare elasticities is presented in the final section of the paper.

\section{TOURISM AND THE U.S. BALANCE OF INTERNATIONAL PAYMENTS}

Expenditures by residents of foreign countries on tourism in the United States represent an export in the U.S. balance of international payments. Expenditures by residents of the United States on tourism in foreign countries represent an import to the United States.

U.S. tourism exports (receipts from foreign tourists) have remained a relatively constant percentage of total exports of goods and services over the period 1960-81 (Table 1). In 1981, tourism exports were $\$ 14.623$ billion, and this amounted to 3.9 percent of total exports of goods and services. Over the 1960-81 period, tourist exports were usually between 3.5 and 4.0 percent of the total.

\footnotetext{
\#An earlier version of this paper was presented at the Atlantic Economic Conference, Miami Beach, Florida, October $8,1982$.

*Florida Atlantic University
} 
TABLE 1

TOURISM AND THE U.S. BALANCE OF INTERNATIONAL PAYMENTS $1960-1981(\$ B I L L I O N)$

\begin{tabular}{|c|c|c|c|c|c|c|c|c|}
\hline \multirow[b]{2}{*}{ Year } & \multicolumn{3}{|c|}{ Tourism } & \multicolumn{3}{|c|}{ Goods and Services ${ }^{a}$} & \multicolumn{2}{|c|}{ Tourism Share (\%) } \\
\hline & Exports & Imports & $\overline{\text { Balance }}$ & Exports & Imports & Balance & Exports & Imports \\
\hline 1960 & 1.1 & 2.3 & -1.2 & 28.9 & 23.7 & 5.2 & 3.8 & 9.5 \\
\hline 1965 & 1.7 & 3.2 & -1.5 & 41.1 & 32.8 & 8.3 & 4.0 & 9.6 \\
\hline 1970 & 2.7 & 5.2 & -2.5 & 65.7 & 60.0 & 5.7 & 4.1 & 8.7 \\
\hline 1975 & 5.5 & 8.7 & -3.2 & 155.7 & 132.8 & 22.9 & 3.5 & 6.5 \\
\hline 1980 & 12.1 & 14.0 & -1.5 & 342.1 & 333.8 & 8.3 & 3.5 & 4.2 \\
\hline 1981 & 14.6 & 15.9 & -1.3 & 372.9 & 361.8 & 11.1 & 3.9 & 4.4 \\
\hline
\end{tabular}

Sources: Bolyard (1982), Survey of Current Business, March 1981 for Goods and Services in 1980, and back issues for the annual articles on foreign travel. Business Conditions Digest (BCD) for historical data on goods and services.

aExcluding transactions under military grants. 
U.S tourism imports (expenditures by U.S. residents abroad) have declined in importance relative to total imports of goods and services since 1970. In 1981, U.S. tourism imports were $\$ 15.947$ billion or 4.2 percent of total imports. This was less than half the share accounted for by tourist imports during the 1960's.

Although tourist exports have increased much more rapidly than tourist imports (14 percent versus 10 percent compound annual growth rate), imports have remained larger than exports, so that the tourist account of the balance of international payments was in deficit throughout the entire period. However, the size of the deficit has declined substantially since the last half of the 1970's.

Trade statistics in the balance of payments are reported on an fob " free on board") or a cif ("costs insurance and freight") basis, depending upon whether the cost of transporting the items are included or excluded in the reported data. For the case of tourism the distinction between fob and cif amounts to a distinction between "travel" expenditures, namely, expenditures which take place in the country visited, and "tourist" expenditures which consist of travel expenditures plus the cost of transporting the tourist to the country that is visited. The latter is referred to as the transoceanic fare in the U.S. balance of payments statistics.

Tourist exports and imports disaggregated into expenditures for travel (food, lodging, entertainment and shopping) and expenditures for transportation (passenger fares) are provided in Table 2. The transportation data refer only to fares paid by foreign residents to U.S. carriers, and by U.S. residents to foreign carriers." These fares are referred to as "transoceanic" because expenditures for domestic travel are normally received by the country in which the travels takes place.

In 1981, U.S. receipts of expenditures by foreign tourists were $\$ 10.058$ billion for travel and $\$ 2.053$ billion for transportation, while foreign receipts of U.S. tourist expenditures were $\$ 10.397$ billion for travel and $\$ 3.607$ billion for transportation. Inflows and outflows under the travel account were much larger than flows under the transportation account throughout the twenty-two year period. This does not mean that transportation expenditures were only a small part of trip expenditures; rather, it reflects the tendency of tourists to use airlines owned by residents of their own country for transportation.

The transportation account has been in deficit during the entire 19601981 period. The deficit has risen during the 1970's, probabaly as a result of the airfare increases due to the sharp increases in oil prices. After rising in the early 1970's, the travel account deficit diminished and the account was actually in surplus in the latest year.

Travel receipts from overseas visitors, and expenditures by U.S. residents for travel overseas are also given in Table 2. The term overseas is used in this context to separate Mexico and Canada from other foreign countries. Overseas countries consist of all foreign countries except Mexico and Canada. Travel to and from the latter countries is different in many characteristics from overseas travel. Both Canada and Mexico have sizeable border travel of very short duration and, almost always, such travel is 
TABLE 2

TOURIST EXPORTS AND IMPORTS FOR TRAVEL AND TRANSPORTATION $1960-1981$ (\$ BILLION)

\begin{tabular}{|c|c|c|c|c|c|c|c|c|c|c|c|}
\hline \multirow[b]{2}{*}{ Year } & \multicolumn{3}{|c|}{ Passenger Fares } & \multicolumn{3}{|c|}{ All Foreign Travel } & \multicolumn{3}{|c|}{ Overseas Travel Only } & \multicolumn{2}{|c|}{ Overseas Share $(\%$} \\
\hline & Rec. & Exp. & Bal. & Rec. & Exp. & Bal. & Rec. & Exp. & Bal. & Rec. & Exp. \\
\hline 1960 & 0.106 & 0.513 & -0.407 & 0.981 & 1.750 & -0.769 & 0.224 & 0.987 & -0.763 & 22.8 & 56.4 \\
\hline 1965 & 0.271 & 0.720 & -0.449 & 1.380 & 2.438 & -1.058 & 0.500 & 1.298 & -0.798 & 36.2 & 53.2 \\
\hline 1970 & 0.377 & 1.215 & -0.838 & 2.331 & 3.980 & -1.649 & 0.889 & 2.184 & -1.295 & 38.1 & 54.9 \\
\hline 1975 & 0.767 & 2.263 & -1.496 & 4.697 & 6.417 & -1.720 & 1.825 & 3.474 & -1.649 & 38.9 & 54.1 \\
\hline 1980 & 2.053 & 3.607 & -1.554 & 10.058 & 10.397 & -0.339 & 5.108 & 6.016 & -0.908 & 50.8 & 57.9 \\
\hline 1981 & 2.455 & 4.487 & -2.032 & 12.168 & 11.460 & +0.708 & 5.716 & 6.547 & -0.831 & 47.0 & 57.1 \\
\hline
\end{tabular}

Sources: Survey of Current Business as in previous Table. Some 1980 figures were estimated by the author on the basis of incomplete data. 
by automobile. Border travel may also have a relatively large shopping of business component when compared to overseas travel.

In 1981, U.S. overseas travel exports (fares are not included) amounted to $\$ 5.716$ billion which was almost 47 percent of total travel exports. U.S. overseas travel imports were $\$ 6.547$ billion or over 57 percent of total travel imports. There was a deficit on the overseas travel account of $\$ 831$ million.

The percentage share figures in Table 2 show a dramatic contrast between the two sides of the overseas travel account. The share of travel exports accounted for by overseas visitors has more than doubled since 1960, while the share of imports accounted for by U.S. travel overseas has remained relatively stable. Travel by overseas residents in the U.S. has increased dramatically, and represents a major source of demand for the U.S. travel industry.

\section{OVERSEAS TRAVEL BY REGION}

Receipts from overseas tourists (travel exports) and expenditures by U.S. travelers overseas (travel exports) distinguished by region of the world and excluding passenger fares for transoceanic travel, are shown in Tables 3 and 4 . The regional classification is the most comprehensive for which reasonably consistent data are available over the entire period.

In 1981, Western Europeans spent $\$ 2.152$ billion on travel in the United States and this amounted to 34.7 percent of the total. Central Americans and residents of the West Indies and Caribbean spent $\$ 0.474$ billion (over 8 percent) and South Americans spent $\$ 1.108$ billion or almost 20 percent. The remainder was spent by residents of the Rest of the World, primarily Japan and Oceania.

Travel expenditures are the product of the number of tourists and their average per capita expenditure. Table 5 shows that the most rapid growth in the number of visitors occurred among residents of Europe and the Rest of the World, although South American visitors have grown most rapidly since 1975 .

The per capita expenditures in Table 6 show that the highest expenditures are made by South Americans, the next highest by Rest of the World (Japanese), then Western Europeans and finally Central Americans.

An important determinant of per capita expenditures is the purpose of visit by the tourist ${ }^{2}$ (Table 7). An overseas resident may visit the U.S. for one of three possible reasons: business, pleasure, other (transit or study). The expenditures of persons in transit are usually very low, and the expenditures of persons visiting for study are very high because the former stay a very short period of time, and the latter have an extended stay. Thus, the results for the small other category represent a mix of two extreme cases. Business visitors have relatively high per capita expenditures, and pleasure visitors have relatively low expenditures. The latter spend a relatively large part of their stay visiting friends and relatives. 
TABLE 3

U.S. RECEIPTS FROM OVERSEAS VISITORS 1960-1981

(\$ BILLION AND PERCENT)a

\begin{tabular}{|c|c|c|c|c|c|c|c|c|c|c|}
\hline \multirow[b]{2}{*}{ Year } & \multicolumn{2}{|c|}{ Total } & \multicolumn{2}{|c|}{ Westcin Europe } & \multicolumn{2}{|c|}{$\underline{\text { Central America' }}^{\prime}$} & \multicolumn{2}{|c|}{ South America } & \multicolumn{2}{|c|}{ Rest of the World } \\
\hline & $\%$ & $\%$ & $\$ \mathrm{~B}$ & $\%$ & $\$ \mathrm{~B}$ & $\%$ & $\$ \mathrm{~B}$ & $\%$ & $\$ B$ & $\%$ \\
\hline 1960 & 0.224 & 100.0 & 0.087 & 38.8 & 0.040 & 17.9 & 0.046 & 20.5 & 0.051 & 22.8 \\
\hline 1965 & 0.500 & 100.0 & 0.200 & 40.0 & 0.093 & 18.6 & 0.107 & 21.4 & 0.100 & 20.0 \\
\hline 1970 & 0.889 & 100.0 & 0.318 & 35.8 & 0.170 & 19.1 & 1.164 & 18.4 & 0.237 & 26.7 \\
\hline 1975 & 1.825 & 100.0 & 0.611 & 33.5 & 0.206 & 11.3 & 1.303 & 16.6 & 0.705 & 38.6 \\
\hline 1980 & 5.108 & 100.0 & 1.942 & 38.0 & 0.417 & 8.2 & 1.277 & 19.1 & 1.772 & 34.5 \\
\hline 1981 & 5.716 & 100.0 & 2.152 & 37.7 & 0.474 & 8.3 & 1.108 & 19.4 & 1.982 & 34.7 \\
\hline
\end{tabular}

"Source: Survey of Current Business annual articles on travel (Bolyard 1982). The figures for Western Europe in the early 1960's were estimated by the author from figures given for Europe and the Mediterranean area using the closest relationship in the year for which both figures were available.

'Includes the West Indies or Caribbean.

Includes Africa, Asia and Oceania. Japan is a major part of this total. 
TABLE 4

U.S. EXPENDITURES FOR OVERSEAS TRAVEL 1960 - 1981

$\left(\$\right.$ BILLION) ${ }^{a}$

\begin{tabular}{|c|c|c|c|c|c|c|c|c|c|c|}
\hline \multirow[b]{2}{*}{ Year } & \multicolumn{2}{|c|}{ Total } & \multicolumn{2}{|c|}{ Western Europe } & \multicolumn{2}{|c|}{ Central America } & \multicolumn{2}{|c|}{ South America } & \multicolumn{2}{|c|}{ Rest of World } \\
\hline & Exp. & Surplus & Exp. & Surplus & Exp. & Surplus & Exp. & Surplus & Exp. & Surplus \\
\hline 1960 & 0.987 & -0.763 & 0.643 & -0.556 & 0.166 & -0.126 & 0.045 & 0.001 & 0.133 & -0.082 \\
\hline 1965 & 1.298 & -0.798 & 0.795 & -0.595 & 0.220 & -0.127 & 0.068 & 0.039 & 0.215 & -0.115 \\
\hline 1970 & 2.184 & -1.295 & 1.310 & -0.992 & 0.390 & -0.220 & 0.090 & 0.074 & 0.394 & -0.157 \\
\hline 1975 & 3.474 & -1.649 & 1.709 & -1.098 & 0.787 & -0.581 & 0.242 & 0.061 & 0.736 & -0.031 \\
\hline 1980 & 6.016 & -0.908 & 3.021 & -1.079 & 1.134 & -0.717 & 0.392 & 0.585 & 1.078 & 0.694 \\
\hline 1981 & 6.547 & -0.831 & 3.123 & -0.917 & 1.277 & -0.803 & 0.383 & 0.725 & 1.300 & 0.682 \\
\hline
\end{tabular}

"See footnotes to Table 3.

TABLE 5

FLOWS OF OVERSEAS TOURISTS INTO AND OUT OF THE UNITED STATES (THOUSANDS)

\begin{tabular}{|c|c|c|c|c|c|c|c|c|c|c|c|c|c|c|c|}
\hline \multirow[b]{2}{*}{ Year } & \multicolumn{3}{|c|}{ Total } & \multicolumn{3}{|c|}{ Europe } & \multicolumn{3}{|c|}{ Central America } & \multicolumn{3}{|c|}{ South America } & \multicolumn{3}{|c|}{ Rest of World } \\
\hline & $\begin{array}{l}\text { In- } \\
\text { flow }\end{array}$ & $\begin{array}{l}\text { Out- } \\
\text { flow }\end{array}$ & $\begin{array}{l}\text { Sur- } \\
\text { plus }\end{array}$ & $\begin{array}{l}\text { In- } \\
\text { flow }\end{array}$ & $\begin{array}{l}\text { Out- } \\
\text { flow }\end{array}$ & $\begin{array}{l}\text { Sur- } \\
\text { plus }\end{array}$ & $\begin{array}{l}\text { In- } \\
\text { flow }\end{array}$ & $\begin{array}{l}\text { Out- } \\
\text { flow }\end{array}$ & $\begin{array}{l}\text { Sur- } \\
\text { plus }\end{array}$ & $\begin{array}{l}\text { In- } \\
\text { flow }\end{array}$ & $\begin{array}{l}\text { Out- } \\
\text { flow }\end{array}$ & $\begin{array}{l}\text { Sur- } \\
\text { plus }\end{array}$ & $\begin{array}{l}\text { In- } \\
\text { flow }\end{array}$ & $\begin{array}{l}\text { Out- } \\
\text { flow }\end{array}$ & $\begin{array}{l}\text { Sur- } \\
\text { plus }\end{array}$ \\
\hline 1960 & 602 & 1634 & -1032 & 267 & 832 & -565 & 144 & 641 & -497 & 105 & 71 & 34 & 86 & 90 & -4 \\
\hline 1965 & 1204 & 2623 & $-\mathrm{J} 419$ & 570 & 1405 & -835 & 264 & 891 & -627 & 186 & 127 & 59 & 184 & 200 & -16 \\
\hline 1970 & 2228 & 5260 & -3032 & 984 & 2898 & -1914 & 484 & 1663 & -1179 & 318 & 249 & 69 & 502 & 450 & 52 \\
\hline 1975 & 3674 & 6354 & -2680 & 1500 & 3185 & -1685 & 478 & 2065 & -1587 & 438 & 447 & -9 & 1258 & 657 & 601 \\
\hline 1980 & 7706 & 8163 & -457 & 3368 & 3934 & -566 & 835 & 2624 & -1789 & 1168 & 594 & 574 & 2335 & 1011 & 1324 \\
\hline 1981 & 8069 & 8040 & 29 & 3530 & 3931 & -401 & 869 & 2453 & -1584 & 1221 & 567 & 654 & 2449 & 1089 & 1360 \\
\hline
\end{tabular}


TABLE 6

PER CAPITA EXPENDITURES BY OVERSEAS VISITORS TO THE U.S. $1960-1981(\$)$

\begin{tabular}{lccccc} 
& $\begin{array}{c}\text { Total } \\
\text { Overseas }\end{array}$ & $\begin{array}{c}\text { Western } \\
\text { Europe }\end{array}$ & $\begin{array}{c}\text { Central } \\
\text { America }\end{array}$ & $\begin{array}{c}\text { South } \\
\text { America }\end{array}$ & $\begin{array}{c}\text { Rest of } \\
\text { World }\end{array}$ \\
\hline 1960 & 372 & 340 & 278 & 438 & 526 \\
1965 & 415 & 369 & 352 & 575 & 472 \\
1970 & 389 & 323 & 351 & 516 & 472 \\
1980 & 662 & 576 & 499 & 836 & 759 \\
1981 & 708 & 609 & 545 & 908 & 809 \\
\hline
\end{tabular}

The proportions of overseas arrivals in the U.S. accounted for by pleasure travelers from each of the four regions of the world are given in Table 8. The table shows that the growth in the importance of pleasure travel was most rapid for Western Europe and the Rest of the World, and these were the areas with the slowest growth in per capita expenditure. Correspondingly, the most rapid growth in expenditures per capita was in Central and South America, the regions with the slowest growth in the share of pleasure travel. ${ }^{3}$

A second factor that is important for explaining per capita expenditures is length of stay. Such data are not available over the 1960-1980 period, although figures for 1979 have been developed by the author. One of the major determinants of length of stay is distance traveled to the U.S. because tourists tend to spread the (fixed) transportation cost over a large number of days the higher is the cost incurred. This role of length of stay is evident from Table 6 where per capita expenditures are seen to be positively correlated with distance from the U.S. Western European and Cen-

TABLE 7

EXPENDITURES AND RELATED CHARACTERISTICS OF OVERSEAS VISITORS BY PURPOSE OF VISIT 1979

\begin{tabular}{|c|c|c|c|}
\hline & Business & Pleasure & Other \\
\hline Total Expenditures Per Person & $\$ 1754$ & $\$ 1299$ & $\$ 2419$ \\
\hline Transoceanic Fare & $\$ 807$ & $\$ 526$ & $\$ 701$ \\
\hline Party Size (Persons) & 1.6 & 2.1 & 1.6 \\
\hline Expenditures in U.S. & $\$ 840$ & $\$ 656$ & $\$ 1399$ \\
\hline Length of Stay (Nights) & 12.1 & 18.6 & 31.7 \\
\hline Expenditures Per Person Per Day & $\$ \quad 69$ & $\$ 35$ & $\$ 44$ \\
\hline Nights with Friends/Relatives & 1.6 & 9.1 & 7.2 \\
\hline
\end{tabular}

Source: These data were derived from a detailed study by the author of the responses received by the Balance of Payments Division of the U.S. Department of Commerce to their 1979 survey of overseas visitors. This detailed study is unpublished, but is under preparation for publication. 
TABLE 8

PLEASURE VISITORS AS A PROPORTION OF ALL ARRIVALS 1960 - 1980 (PERCENT)

\begin{tabular}{cccccc} 
& $\begin{array}{c}\text { Total } \\
\text { Overseas }\end{array}$ & $\begin{array}{c}\text { Western } \\
\text { Europe }\end{array}$ & $\begin{array}{c}\text { Central } \\
\text { America }\end{array}$ & $\begin{array}{c}\text { South } \\
\text { America }\end{array}$ & $\begin{array}{c}\text { Rest of } \\
\text { World }\end{array}$ \\
\hline 1960 & 64.0 & 58.6 & 75.0 & 70.5 & 54.6 \\
1965 & 71.6 & 67.0 & 84.5 & 81.7 & 59.4 \\
1970 & 74.6 & 73.8 & 86.8 & 80.2 & 60.8 \\
1975 & 79.2 & 77.3 & 84.9 & 84.5 & 77.4 \\
1980 & 81.9 & 80.8 & 85.6 & 88.4 & 78.9 \\
1981 & 81.0 & 80.4 & 85.0 & 87.2 & 77.2 \\
\hline
\end{tabular}

tral Americans are relatively close and have relatively low per capita expenditures. Rest of the World residents and at least some South Americans are relatively far and have higher per capita expenditures.

Finally, expenditures per capita are relatively high by Central and South Americans because shopping is an important part of their trips. Shopping will be more important the less available or more expensive are consumer durables in the home country, and the closer is the home country to the U.S. These two factors are present for much of Central America and the West Indies, and for the Northern Part of South America (Venezuela and Columbia).

\section{INCOME AND PRICE ELASTICITIES OF OVERSEAS TOURIST DEMAND}

Economic theory suggests that principal determinants of travel expenditures by overseas tourists in the United States will be the U.S. price level relative to prices overseas expressed in dollars, and the purchasing power of overseas income in the United States. Five observations on the relevant variables are presented in Table $9 .{ }^{4}$

After adjustment for inflation, it is clear that the overseas travel expenditures had two exceptionally strong growth periods: $1960-65$ and 1975-80. The first period was characterized by slow U.S. inflation relative to overseas countries, a declining cost of air travel and rapid income growth. The growth in overseas travel to the United States was slower during 1965-70 as European devaluations eroded the U.S. price advantage. In 1970-75, the sharp rise in airfares and devaluation of the dollar prevented the rise in foreign income from exerting its full impact on overseas visitors. Moderation in airfares and a relatively rapid rise in overseas incomes during 1975-80 led to very rapid growth in overseas spending in the United States.

Regression of overseas travel expenditures (exclusive of airfare) against overseas income, U.S. to overseas prices and the transatlantic airfare measured in dollars are presented in Table 10. All variables were measured in logarithms so that the coefficients can be interpreted as elasticities. 


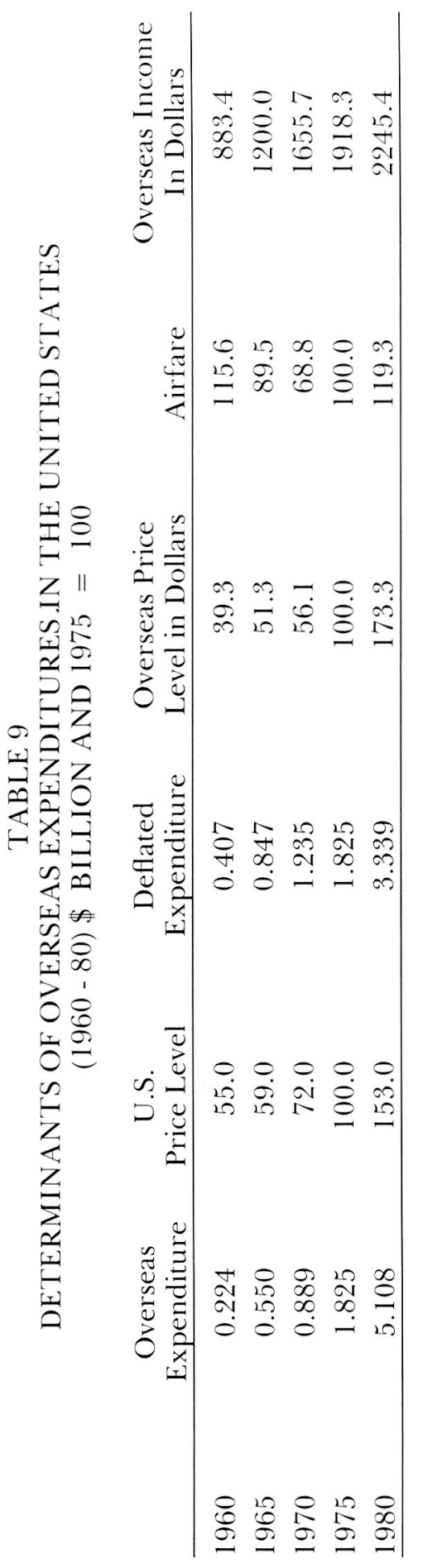


The results show that overseas travel expenditures (in dollars) are income inelastic (when income is measured in dollars) but price elastic. They are also inelastic with respect to the dollar airfare.

The income inelasticity and price elasticity of overseas tourist expenditures in the United States contrasts with the findings of several other studies of tourism. Previous studies have typically found income elasticity but price inelasticity (Stronge and Redman 1982 and the references cited there). However, those studies typically measured tourists' income in terms of the home currency, and this was not possible here because of the need to aggregate across countries.

The large price elasticity may reflect a large exchange rate elasticity, since the latter is well known to potential consumers throughout the world. The large price elasticity relative to the elasticity with respect to income suggests that the rapid increase in overseas tourism in the United States during 1960-80 has been a result of favorable price rather than income effects. The measurement of income in dollars, however, means that a devaluation of the dollar will affect foreign income as well as the price ration in the demand function. Indeed, a devaluation could also affect the transoceanic airfare, although agreements about such fares tend to be denominated in dollars. Thus, the results in Table 10 suggest that exchange rates have powerful effects on the demand by overseas residents for tourism in the United States.

TABLE 10

REGRESSIONS FOR OVERSEAS TRAVEL EXPENDITURES ${ }^{a}$

\begin{tabular}{lcccccc} 
& Income & U.S. Price & Fare & $\mathrm{R}^{2}$ & $\mathrm{DW}$ & $\hat{\mathrm{p}}$ \\
\hline Total Visitors & .53 & -1.81 & -.79 & .99 & 1.54 & .23 \\
& $(.46)$ & $(.29)$ & $(.35)$ & & & \\
Western Europe & .84 & -1.42 & -.67 & .98 & 1.06 & .47 \\
& $(.72)$ & $(.68)$ & $(.50)$ & & & \\
Central America & .072 & -1.27 & -.82 & .93 & .85 & .52 \\
& $(.12)$ & $(.70)$ & $(.26)$ & & & \\
South America & .88 & .073 & -.42 & .89 & .39 & .83 \\
& $(.22)$ & $(.59)$ & $(.46)$ & & & \\
Rest of World & 1.24 & -1.31 & -.26 & .99 & 1.25 & .30 \\
& $(.48)$ & $(.20)$ & $(.55)$ & & & \\
Western Europe & 1.57 & -.85 & -.34 & .98 & 1.71 & .14 \\
& $(.64)$ & $(.38)$ & $(.44)$ & & & \\
Central America $^{\mathrm{b}}$ & .10 & -1.13 & -.90 & .95 & 2.05 & -.07 \\
& $(.18)$ & $(.80)$ & $(.27)$ & & & \\
South America $^{\mathrm{b}}$ & .71 & -.41 & -.97 & .97 & 1.08 & .45 \\
& $(.22)$ & $(.40)$ & $(.30)$ & & & \\
\hline
\end{tabular}

Standard Errors are written below the coefficients in parentheses.

'Adjusted for serial correlation using the Cochrane-Orcutt procedure. 
The implication of these results is that the rapid increase in overseas tourism to the United States during the period 1960-80 was primarily due to favorable price developments, rather than to a growth in overseas income.

Considering the results for the four overseas regions in Table 10, the ordinary least squares estimates for Western Europe and the Rest of the World (primarily Japan) differ substantially in their income and airfare elasticities. The Rest of the World countries' expenditure to the United States are income elastic but relatively insensitive to airfares, whereas European expenditures are income inelastic, but more sensitive to prices and much more sensitive to airfares.

These findings are consistent with the view that long distance travelers (Rest of the World and South America) have tourist expenditures with the higest income elasticity and the lowest airfare elasticities; short haul travelers (Central America and Western Europe) have the lowest income elasticity and the highest airfare elasticity. Since length of stay is strongly

TABLE 11

RESIDUALS FROM THE ORDINARY LEAST SQUARES REGRESSIONS (PERCENT)

\begin{tabular}{lrrrrr} 
& $\begin{array}{c}\text { Total } \\
\text { Overseas }\end{array}$ & $\begin{array}{c}\text { Western } \\
\text { Europe }\end{array}$ & $\begin{array}{c}\text { Central } \\
\text { America }\end{array}$ & $\begin{array}{c}\text { South } \\
\text { America }\end{array}$ & $\begin{array}{r}\text { Rest of } \\
\text { World }\end{array}$ \\
\hline 1960 & 2.2 & 1.3 & -15.9 & -12.0 & 13.7 \\
1961 & -3.2 & -6.1 & -16.6 & -16.7 & 2.6 \\
1962 & -7.5 & -8.3 & -4.1 & -8.1 & -7.4 \\
1963 & -7.4 & -15.6 & 8.2 & 8.9 & -0.8 \\
1964 & 8.8 & 9.7 & 4.4 & 1.9 & 5.5 \\
1965 & -1.7 & 18.0 & 16.7 & 17.7 & 3.6 \\
1966 & 7.1 & 8.1 & 15.7 & 21.9 & -3.0 \\
1967 & 7.4 & 8.1 & 18.2 & 26.1 & -9.9 \\
1968 & 6.0 & 5.4 & 8.7 & 13.6 & -13.1 \\
1969 & -0.4 & 10.9 & -2.3 & 5.8 & -13.1 \\
1970 & 2.7 & 0.6 & 3.1 & 0.4 & 1.9 \\
1971 & -2.8 & -3.8 & -8.4 & -13.6 & 2.7 \\
1972 & -7.4 & -5.8 & -14.5 & -15.0 & -0.2 \\
1973 & -11.5 & -12.0 & -5.9 & -25.2 & 1.9 \\
1974 & -3.6 & -11.0 & -4.6 & -39.5 & 3.5 \\
1975 & -7.4 & -22.2 & -18.6 & -18.0 & 4.2 \\
1976 & 10.5 & 8.4 & 7.5 & -11.9 & 16.4 \\
1977 & 3.3 & 8.7 & -2.0 & -4.0 & -1.9 \\
1978 & -3.7 & 7.1 & 2.1 & 21.1 & -21.5 \\
1979 & 6.0 & 7.0 & 8.3 & 20.7 & 2.5 \\
1980 & 2.7 & 1.7 & -0.4 & 25.8 & 14.8 \\
\hline & & & & &
\end{tabular}


positively correlated with distance tráveled, long distance travelers reduce the airfare cost per day in the United States and, hence, their expenditures are relatively insensitive to this variable. Short haul travelers incur relatively high per day airfare costs and so their expenditures are more sensitive to these costs. Because long distance travelers stay a long period, their expenditures in the United States are more in line with their income than short haul travelers. The latter may visit relatives or friends and, hence, have low expenditures relative to their income or, indeed, they may live at a standard far above the level to which they are accustomed (during a visit to the United States).

The results of making a Cochrane-Orcutt adjustment for serial correlation are also presented in Table 10. The price of the gain in efficiency is considerable instability in the coefficients. Given the small number of observations, the asymptotic properties of the Cochrane-Orcutt estimator provide little support for preferring these estimators. ${ }^{5}$

The autocorrelation in the disturbances may reflect inappropriate lag structures, but the data are inadequate to pursue this line of research. The autocorrelation also reflects another problem, however. The residuals from the ordinary least squares equations are given in Table 11, and they can be interpreted as the proportionate underestimation of expenditures by the relevant equation.

Note the large residuals in 1965 for Western Europe, Central and South America, and the large residuals in 1976, particularly for the Rest of the World. These are partly due to special events in the United States (the 1965 World's Fair in New York and the Bicentennial Celebrations). The large residuals for Central and South America in 1967 may reflect stopovers in the United States by visitors to EXPO 67 in Montreal. Other events, such as the Olympic Games, may also help or hinder overseas tourism in the U.S. depending on where they occur. These special factors introduce heteroscedasticity into the disturbances. When the sample size is small, the outliers may distort the estimated regression line and introduce autocorrelated disturbances.

\section{FOOTNOTES}

'The tourist data in Table 1 have been developed for balance of international payments purposes and, therefore, they understate the magnitude of the industry. The international payments accounts are designed to measure monetary flows between the United States and foreign countries, and the tourist data in these accounts show expenditures by foreign residents that are received by U.S. residents, and expenditures by U.S. residents that are received by residents of foreign countries. In particular, expenditures by U.S. residents received by U.S. airlines, and the value added by U.S. tour operators to the cost of a package tour overseas, are excluded from U.S. tourist imports. Similarly, expenditures by foreign residents received by foreign airlines or as payment for services by foreign tour operators are excluded from tourist exports. Because many U.S. residents travel on U.S. airlines, and many foreign residents travel on foreign airlines, the exports and imports of tourism substantially understate total tourist expenditures.
'Some of the statements in the following paragraphs, such as the high per capita expenditures by business travelers and the changes in the importance of student and transit visitors are substantiated in an unpublished manuscript under development by the author.

"Additionally, the Central and South American pleasure share increased as a result of a decline in the importance of those in transit; the relative decline of transit was also a factor for Western Europe and the Rest of the World, but those areas experienced a decline in the relative importance of business travel also. Finally, the Rest of the World is the main source of those visiting the U.S. for study. The latter spend relatively large amounts because of a long stay but this share in Rest of the World travel has also declined.

${ }^{4}$ The overseas price level in Table 9 was obtained as an implicit deflator by deflating expenditures by Western Europeans, Central and South Americans and Rest of 
the World residents. Consumer price indexes for each of these areas were divided by exchange rate indexes to convert them to dollars. All data were obtained from International Financial Statistics, May 1981 and International Financial Statistics Yearbook 1980. The consumer price indexes for Western Europe were computed as a weighted average of the indexes for France, Germany,

Italy, Netherlands, Sweden, Switzerland and the United Kingdom, using 1975 shares in U.S. overseas travel exports as weights. A similar procedure was used for gross domestic product. Venezuelan data were used for South America, and Japanese data were used for the Rest of the World. Bahamian data were used for Central America. The relationship between Bahamian and Venezuelan prices was used to estimate a consumer price index for the Bahamas in the 1960's.

No satisfactory measure of transoceanic fares ís available. The U.S. Department of Commerce produces a measure of per capita airfare for U.S. travelers to Europe.
This measure is similar to a unit value index in that it does not control for changes in the "commodity" composition. That is, it does not allow for a change in the distance traveled within Europe, changes in the traveling party size of the type of fare (class, charter and so on). The airfare was converted to an index (base $1975=100$ ).

${ }^{5}$ The equations were also estimated using Zellner's seemingly unrelated regressions procedures. The Zellner procedure resulted in estimated equations with significant autocorrelation.

\section{REFERENCES}

Stronge, W. and M. Redman (1982) "U.S. Tourism in Mexico," Annals of Tourism Research, Vol. 9, 1; 21-36. Bolyard, J. E. (1982) "International Travel and Passenger Fares 1981," Survey of Current Business, 62, 6; 3235,72 . 